\title{
Genocide at Rangpur City in the Liberation War of Bangladesh, 1971: Fire, Fury and Fragrance
}

Md. Mohoshin Reza*

\begin{abstract}
During the liberation of 1971, the city of Rangpur received a monstrous genocide having nearly 20,000 houses demolished and approximately 50,000 people killed. Indeed, the genocide commenced at Rangpur from $3^{\text {rd }}$ March, 1971, resulting the martyrdom of Shanku Shamajhdar, presumed to be the first martyr of the liberation movement, and his comrades. After that, people's revengeful attack on armies on $17^{\text {th }}$ March, Santal leader Bundo Odaon's joining with the Bengalis, their joint attack on Rangpur Cantonment, their retreat and finally, there occurred the outrageous spread out of genocide at Rangpur causing unnumbered mass execution fields. The earlier researches already identified 35-40 execution fields at Rangpur. As per the present research, the number of the execution fields is 51 with possibility of more to be identified. This work attempts to find the shape of the genocide at Rangpur, explore the unfound execution fields, and describe past and present position of the related affairs.
\end{abstract}

Keywords: Genocide, Liberation War of Bangladesh, The Mass Execution Fields, the First Martyr of the Liberation Movement, Attack on Rangpur Cantonment, Operation Search Light

\footnotetext{
* Corresponding author: Md. Mohoshin Reza, Assistant Professor, Department of English, Bangladesh University of Business and Technology (BUBT), Rupnagar, Mirpur 2, Dhaka, Bangladesh, E-mail: $\underline{\text { mohoshinreza@bubt.edu.bd }}$
} 


\section{Introduction}

From $3^{\text {rd }}$ March up to $16^{\text {th }}$ December 1971, the genocide at Rangpur, operated by the Pakistani invading army, took a dreadful shape during the liberation war of Bangladesh. The process of mass killing was going on randomly everywhere across the district of Rangpur; especially, at the proper Thana. Besides the wide spread scattering assassinations, the invading armies killed thousands of people in a mass in various execution fields. The mass execution fields in Rangpur proper Thana, where people were taken in masses and killed plan wise, may presumably exceed 100 in number. Through physical investigations and interviewing the people, first hand witnesses, it is reported that besides the identified fields, people were killed here and there and now and then. Including these types of temporarily marked spots, the total fields of homicide may exceed 200 in number. There are execution fields in Rangpur proper Thana within and beyond the city corporation area. The present research attempts to explore and survey the number of the mass execution fields, and appraise the common motif of the Pakistani armies behind the mass assassination. The research is limited to Rangpur proper Thana only.

\section{Research Methodology}

In the process of conducting the research, methods which have been used are:

1. Field survey by inspection, observation, interviewing and focus group discussion

2. Comparing, contrasting and generalizing the obtained data

3. Data collection from secondary sources like books, prior research works, research reports conducted on the execution fields of Rangpu

Following the above mentioned methods, data on the mass execution fields in the liberation war of 1971, limited to Rangpur proper Thana, have been presented below. 


\section{The City of Rangpur on the Eve of the Liberation War of Bangladesh}

Rangpur before the Historic $7^{\text {th }}$ March, 1971

On the March 01, 1971, all on a sudden, the session of the National Assembly was postponed. In response to the dissenting call of the leader of the nation Bangabandhu Sheikh Mujibur Rahman, people of Rangpur city brought a procession protesting the political gaming by Pakistan government. Mukhtar Elahi, then vice president (V.P) to Carmichael College Students Union (CACSU) was leading the procession. Shariful Alam, a student of Carmichael College, was carrying the national flag of independent Bangladesh for the first time at Rangpur (Ahsan, 1994, 26). When the procession reached the Ghoda Pir Majar area of the city, police and some pro-Pakistani Biharies (non Bengalis) attacked the procession. Especially, in cooperation with Pakistani police, a non Bengali named Islam Khan and his gang fired at the procession from the roof top of the office of Export-Import Bureau at Ghoda Pir Majar area of the city. The gun attack caused martyrdom of at least 7-8 Bengalis on the main road at front of the office of Export-Import Bureau (opposite to the branch of Janata Bank).

Martyrdom on the $3^{\text {rd }}$ March, 1971

In the gun fire of $3^{\text {rd }}$ March, 1971, Shanku Shamajhdar, a young man of 17 , first, attained martyrdom who is said to be the first martyr in the movement of the liberation. Along with Shanku Shamajhdar, Omer Ali, Abul Kalam Azad and other 5-6 people died. Omer Ali and Abul Kalam Azad were students of Carmichael College at I. A. class. Shariful who carried the flag of independent Bangladesh for the first time at Rangpur on $3^{\text {rd }}$ March, 1971, was injured at the gun attack and died in the middle of April ' 71 .

A direct witness, Babu Shamajhdar, brother to Shonku Shamajhdar, informed that due to the terror of Pakistani police, militaries and again, the place Ghoda Pir Majar, being adjacent to the Alam Nagar Bihari Colony, none dared take away the dead bodies for burial. That time the Biharies who were working as spies to Pakistanis, became 
increasingly active in collaborating the military and other security forces. As a result, the dead bodies of the martyrs were kept fallen at the road side with receiving no burial. The office of Export-Import Bureau still exists there and presently the place has been occupied by sales men of drugs like Fencidyl, cannabis and so on. Common people of the city do not know that the place is a field of assassination.

Before the formal declaration of freedom, even before the historic speech by Bangabandhu on $7^{\text {th }}$ March, 1971, Shanku Shamajhdar and his comrades laid their lives in the movement of liberation. From this sense, it may be considered that Shanku the first martyr on $3^{\text {rd }}$ March ' 71 at Rangpur is the first martyr of the liberation movement.

Another remarkable thing is that on the $3^{\text {rd }}$ March, 1971, when the national flag of independent Bangladesh was being hoisted for the first time at Dahaka University by the student leaders, the same time the flag was being carried in the procession at Rangpur city.

From $4^{\text {th }}$ March of 1971, the city of Rangpur began to burn in rage of the deaths of Shanku and others. Every where a slogan spread-

\section{"Bansher lathi tairi karo \\ Bangladesh swadhin karo." \\ (Make weapon of bamboo and snatch away the liberty of Bangladesh.)}

Rangpur in between $7^{\text {th }}$ March - $25^{\text {th }}$ March, 1971

The fury of the freedom loving people was on the increase from the very early March of 1971 . On $8^{\text {th }}$ March, 1971, some Pakistani Military officers entered a village named Damodarpur, to arrest some activists of the liberation movement. A Lieutenant Abbas, a Commanding Officer of 29 Cavalry Regiment to Rangpur cantonment led the operation. The army team also attempted to pick up two goats and some other foods of the villagers by force. By this time, it was spread out as a rumour that supply of food in the cantonment had come to finish and the armies came to loot away things of the villages. As a result, hundreds of people from surrounding villages rushed to the spot of the village Damodarpur and attacked the armies. In the fight, Pakistani officers were beaten and killed and their bodies were thrown beside the cantonment of Rangpur. A number of villagers were also killed in the counter attack by 
the armies at Harirampur area of the village Damodarpur. From that time, Rangpur city entered into the war-situation.

13 graves of the Bengali people should have been identified. In cooperation with Baharul Alam, brother to a martyr Hasanul Alam, the researcher found a line of seven graves at Harirampur. Other six graves of the villagers are still unidentified.

\section{Beginning of the War and People's Attack on Rangpur Cantonment}

At the evening of $25^{\text {th }}$ March, 1971, a helicopter landed on Rangpur cantonment and it was spread among the student community that Vutto-Iahya sitting had broken Bangabandhu and a terrible things might occur at night. It was also spread at the city that the Bengali officers were disarmed and were separated from other armies in the cantonment of Rangpur. Some affluent Biharies got shelter inside the cantonment and they were used in spying at the night time operation launched by the Pakistani armies at the city. Indeed, the presumptions were not incorrect. On the black night of $25^{\text {th }}$ March ' 71 when the city of Dhaka was in a complete blood-bath, at the same time militaries launched massacre at Rangpur city as well. Arrests and assassinations were on full swing and the Biharies launched looting and plundering over the city.

After $26^{\text {th }}$ March, with the formal declaration of the Liberation War on behalf of Bangabandhu Sheikh Mujibur Rahman, huge people gathered with great enthusiasm under the leadership of advocate Abdul Gani and his friend aborigine leader Budo Odaon alias Budo Lakda who was a Santal leader. Budo Odaon and advocate Abdul Gani were planning to attack Rangpur Cantonment.

A. Y. Mahmud, known as Jorreas Mian, was an advocate. Jorreas Mian protested against the attack and assassination on the public procession on $3^{\text {rd }}$ March ' 71 by the Pakistani police and non Bengalis. Besides Jorreas Mian, other ten (10) people were taken to the cantonment on $27^{\text {th }}$ March, 1971.

On the evening of $27^{\text {th }}$ March, 1971, a great number of Santal, farmers and other professionals from Mithapukur, Pirganj, Badarganj assembled in the village of Nishbetganj at the camp of Budo Odaon to attack the cantonment. On the $28^{\text {th }}$ March 1971, Budo Odaon and Abdul 
Gani launched their attack on Rangpur cantonment at nearly 8.30 am on $28^{\text {th }}$ March 1971. The attack was launched from four particular sides.

Thousands of bamboo rods, arrows and bows, javelins, big iron sickle etc. were used in the attack. A researcher Sukumar Biswas, with reference to another researcher Mahbub Rahman mentioned-

Before getting the information about the situation inside the cantonment, thousands of enraged people of the villages, began to assemble to the south-west side of the cantonment at Nishbetganj Hat and its neighbouring areas with weapons like-bows-arrows-spearsaxe-bamboo rods in hands. On $28^{\text {th }}$ March, before the noon, the whole area was submerged with people (Biswash, 1987: 35-36).

On the other hand, along the southern road of the cantonment, 1015 jeeps were set with Heavy Machine Guns (HMG) and every point the armies covered with different kinds of fire arms. Within a few minutes, nearly one thousand (1000) patriots fell down at face of fire guns (Ahsan, Op. Cit.: 27).

Sukumar Biswash wrote-

It was seen that dead bodies after dead bodies were fallen all over the roads, fields, crops fields and the river bank of Ghaghat ((Biswash, Ibid.).

After a short while, Pak-armies gathered the bodies of the dead and wounded ones and burned the bodies of all living and dead people with petrol and fire. Some first hand witnesses informed that many wounded people were bayonet charged and killed.

In an interview advocate Abdul Gani said-

"Inside from the cantonment, showers of bullets were coming towards the attackers. As from all sides, they were attacked, the counter attack was also from all side and nearly seven hundred to one thousand people got martyred. Colonel Sagir, a Bengali dalal (collaborator) officer, brought many dead bodies under the military shed of the cantonment. Dead bodies of the martyrs rotted under the shed."

The entire area of the military shed of Rangpur cantonment should be marked as an execution field.

However, having the cantonment attacked by massive people of Rangpur, the military officers were blocked in. People were divided in 
four (04) groups rushing and attacking from particular areas around the cantonment- the areas were Baldipukur, Mithapukur, Badar Ganj, and Nishbet Ganj. Each group consists of at least one thousand (1000) freedom fighters. The cantonment had to face a four sided attacks. By this time, another support of the attackers, EPR (East Pakistan Rifles), ran away.

\title{
Consequence of the Cantonment Attack
}

Inside from the cantonment, militaries replied through a maddening operation over the freedom fighters with machine guns and other heavy weapons. As a result most of the freedom fighters of the four different groups received death at different corners of the cantonment. Advocate Abdul Gani marked-

\begin{abstract}
Already seven hundred to one thousand dead bodies had been taken inside the cantonment by Colonel Sagir. Any more, dead bodies of the martyrs belonging to four particular groups of attackers kept falling at the west side, north-west side, southern part and the south east side of the cantonment. Besides, many dead bodies were fallen scattered around the outer boundary of the cantonment. Nearly three thousands of freedom fighters laid down their lives in that battle. Most dead bodies rotted and were swallowed away with beasts like dogs, foxes and the like.
\end{abstract}

Another witness and also a freedom fighter, participating in the cantonment attack, Abdul Khaleq who presently works as a waiter in a small hotel (Aminur's Hotel) at Thikadar Para Mor in Rangpur, stated-

After the liberation had been over, skeletons were buried wherever found around the cantonment.

From the statement of Advocate Abdul Gani and Abdul Khaleq, it is presumed that the west side, north-west side, southern part and the south east side of the cantonment might be considered as four big execution fields. Again, as the dead bodies of freedom fighters were burnt and some were fallen scattered all around the outer boundary of the cantonment, it is a hypothesis of the researcher that through excavation, 
the whole outer border of the cantonment might be found as a Mass Execution Belt.

However, losing more and more power at the face of heavy weapons of the Pak-armies, finally, the joint group of the Bengalis and Santals retreated on $30^{\text {th }}$ March and the Pak armies came out with faces of demons.

\section{The Genocide on Full Swing and Mass Execution Fields on the Increase}

Advocate Abdul Gani, again, informed-

From $28^{\text {th }}$ March to $30^{\text {th }}$ March, Pak-armies were captured and confined inside the cantonment. $30^{\text {th }}$ March ' 71 , being able to come out, they created massacre at Rangpur city. They damaged the base camp of the aborigine leader Budo Odaon at the village Nishbetganj. They completely demolished the village Nishbetganj and killed presumably one hundred and fifty (150) comrades of Budo Odaon. After that, they killed at least one hundred (100) villagers, keeping them standing on queues on both sides of the main road of the village Nishbetganj.

Presently, there stands the monument "Rakta Gaurab" (The Glory of Blood), in commemoration of the martyrs on the main road of Nishbetganj. Up through the road of the "Rakta Gaurab" (west to the monument and back side of Rangpur Parjatan Kendro), the five (5) kilo metre long road is a brutal field of mass execution in which, every after an interval of 15-16 days, the invading armies brought at least one hundred Bengalis in trucks, with hands and eyes bound and killed them at different spots of the road. Kamal Hossen, a teacher of Darshana High School, Rangpur and the witness said-

At least 100 people were brought by trucks and were killed at the site each time. During the war of nine months, at least one thousand (1000) people were killed in this execution field.

Besides that, the execution fields in which hundreds of people were killed are in the villages e.g. Manjai, Darshana, Darshana Pahari, Upa Shahar and at the western side of Carmichael College, there remain 
10-12 mass execution fields. There are needs of more research and investigation to find other mass killing sites.

Wahiduzzaman Chawdhury, a liberation war researcher marks in an article-

Immediately after $25^{\text {th }}$ March of 1971, Rangpur city was affected by the Pak-armies. I was an enthusiastic observer of their indiscriminate Bengali annihilation process. I recorded the number of the dead ones and dates of the killing by the Pak-armies. I am sure about the authenticity of the information (Chawdhury, ed. M.R. Akhtar Mukul: 449).

As per his writing-

$8^{\text {th }}$ April, 1971: Pak-armies brought forty seven (47) farmers with eyes and hands bound to a place called Narir Hat, two and a half miles west from Rangpur city. There at the spot called Kholahati, they killed all the people.

At present, in this very place Kholahati Cantonment is situated. He writes-

15 ${ }^{\text {th }}$ April, 1971: Pak-armies killed twenty two (22) farmers at Deovog village by brush fire. The place is situated at the south-east side of Rangpur cantonment. The execution field is exactly remains at the south-east side of Damodorpur village on four decimal lands.

15 ${ }^{\text {th }}$ April, 1971: The Pak-soldiers killed thirty two Musalli (people coming to say prayer). They took the people from Deovog mosque and fired them at the north-west corner of the village.

17 ${ }^{\text {th }}$ April, 197: The invaders killed seventeen (17) Bengali Jawans (members) of Bengal Regiment at an irrigation canal. The Jawans were in dress. The canal was two miles north to the ancient origin of Rangpur city Mahiganj.

19 ${ }^{\text {th }}$ April, 1971: One hundred and fifty two (152) E.P.R members were killed through brush fire by the invading soldiers on the bank of the river Ghaghat, floating by the side of Rangpur cantonment. The Pakistani soldiers killed them and pierced bamboos through their dead bodies as if they were making a garland of the dead Bengalis and threw the bamboos in the river Ghaghat.

Through interviewing some elderly people of the area, the present researcher predicts that the execution field is situated under water which 
is situated at the left side of the present main gateway of Rangpur cantonment, nearly 300 metres away from the village Khalifa Tari.

$28^{\text {th }}$ April, 1971, the Pakistani armies launched an operation to capture especially the Hindu families of the teachers of Carmichael College and their family members. Pak-soldiers grabbed six (6) Hindu professors and their family members including Ram Krisna Adhikari, Sunil Baran Chakrabartee, kala Chand Roy, Chitta Ranjan Roy and others. They took the people to Paira Band, the birth place of Rokeya which is nearly six k. m. north from Rangpur city. All members of the families of those six professors were shot down by Pak-armies under a bridge, called Damdama Bridge, presently on Dhaka-Rangpur road. Razib Arman, who cooperated in collecting data from the primary field of the present research, informed that later, many people were taken to the place and killed at different times during the liberation war. Bashu Mia, his uncle, was a victim of the assassinations.

$29^{\text {th }}$ April, 1971, Pak-soldiers killed twenty one (21) Bengalis including a small boy. At the time of investigation, the researcher met Roghunath Dom, a sweeper working in the autopsy of Rangpur Medical College who was a direct witness of the fact. Roghunath said-

\footnotetext{
There were twenty one people. All were on the run being chased by the armies from the main gate way of the cantonment. They were fleeing towards Rangpur Medical College. Finally they were driven at near the Dhap Mor, the place exactly where presently; there is the B.R.T.C bus terminal adjacent to Rangpur Cant. Public School and College. There was a boy of about thirteen. All of them were shot down.
}

From the statement of Raghunath, it comes that on $31^{\text {st }}$ April, further, Pak armies killed one hundred and twenty four (124) members of E.P.R at Darshana Pahadi area. Their bodies were drifted away in the river Ghaghot.

Raghunath also informed that on the very day, some Rajakars convinced 10-12 people of providing with jobs. The people were starving and were seeking foods. The Rajakars took all of them to the cantonment. All were killed near garage of the cantonment.

Liberation war researcher Wahiduzzaman has, again, written- 
The Pak-invading soldiers launched operation at Narir Hat for second time and killed forty eight (48) on $11^{\text {th }}$ May, 1971.

On $16^{\text {th }}$ May ' 71 they launched "Rape motivated attack" on Radha Ballav area of the city. From 9.00 p. m to 01.00 a.m. the operation continued. Nearly one hundred people were martyred.

On $2^{\text {nd }}$ June, 1971, Pak armies took a Brahmin family under the Zafargonj Bridge near the river Ghaghot. They raped the women members of the family and then killed all.

The most terrible homicide of the sector no. 6 took place at the residence of Major Bashir. The house was adjacent to the Army Head Quarter of Rangpur Cantonment. Almost every night during the nine months of liberation war, a number of young girls or women were brought. Pak armies made them dance and finally killed after seduction.

Md. Sultan, a Major Habilder, working at the cantonment that time informed-

Captain Gul and Major Bashir piled up the dead bodies of the women under the military shed of the cantonment.

Conditions provide the notion that the military shed of Rangpur cantonment may be considered as the biggest execution fields in Rangpur. It is predicted that approximately fifteen thousands (15000) people were killed in the place.

On the other hand, liberation war researcher Akhtaruzzaman Mandal has written-

The Biharies (Urdu speaking Pro-Pakistanis) are killing people, uprooting men's eyes, violating women's honour, they are cutting out men's stomachs; triumphing over these, bringing processions with pieces of human organs from the dead bodies of Bengalis. The terror is going on at the suburb area, Mahiganj, Modern area, RangpurSaidpur road and so on. Rangpur and Dinajpur have been declared as "Biharistan" by them (Mandal, 1971: 31.).

The research of Akhtaruzzaman Mandal on Rangpur region provides that approximately six (06) hundred people were killed and buried down indiscriminately at Tajhat, Mahiganj and Modern areas. His research creates notion that Tajhat-Mahiganj-Modern- these three areas might jointly form a big 'Triangle Execution Field'. 
The great student leader and martyr of Rangpur city, Mukhtar Elahi was the chief of the district guerrilla force called "Mujib Bahinee". He launched a good number of successful operations on the invading armies and the Rajakars and in fear of Mukhtar Elahi, enemies could not dare go out of the city at day light. His eldest brother Manjur Elahi was responsible to maintain the main store house of war weapons used in the liberation war at Shahebganj in Kuchbihar. Mukhtar's elder brother Mushtak Elahi organized freedom the freedom fighters at Gaibandha and lalmonirhat and then joined sheikh Fazlul Haq Moni as Assistant Editor to publish the Daily Banglar Bani in Kuchbihar and propagated for the liberation war. Maudud Elahi, another brother studying at Durham University at London, then worked as a media to make communication between the Bengalis obstructed in Pakistan and their relatives. What was the condition of Rangpur city was known from a letter, written to Maudud Elahi by his cousin khairul Islam on $4^{\text {th }}$ May, 1971-

Pak-Millitaries are clutching away the young people of 18 to 30 . They are taking blood out from their bodies to use for own purposes. As a result, many of the victims are getting paralyzed.

A letter to Mr. Maudud Elahi from his father, written on $6^{\text {th }}$ June, 1971, described the condition of Rangpur-

Te city is desolate, no rail or vehicle..........in towns and villages, everywhere the reign of the devils....

Another letter of the father to the son written on $16^{\text {th }}$ November, 1971, described-

A great many homicides had taken place in the city. They burned down our village Badiapara. The head master of Rangpur Zilla School Mr. Maksud Ali committed suicide...... Some days ago, Paksoldiars and Rajakars killed his son (engineer Farrukh Ahmed) recently returned from abroad and others.......Biharies changed the name of Rangpur as "New Bihar".

A Bengali E.P.R Abdul Qadir was caught by Pak armies but was able to escape and save own life. Here is his statement - 
That night we, 33 E.P.R members were fallen bound in a dark room on Rangpur-Saidpur road. It might be at 3.00 a. m, they switched on the search light to kill all of us and suddenly I began to run away... Other thirty two (32) people were killed.

$12^{\text {th }}$ April, 1971, Pak-armies brought people with three trucks at a place called Balar Khal and killed all of them. In that day, the Pakish declared at Rangpur city-

"We will make this country a land of prostitutes and slaves and beggars."

To save own life from this genocide, many Hindus were bound to convert into Muslims. Kamala Prasad, a business man presently living at Saidpur, was one of them. He was also taken to the execution field called Balar Khal. Somehow, he escaped from the spot and was detained for the second time. That time he was forced to convert into Muslim. In the genocide at Balar Khal, a few of the martyrs are-Dr. Zikrul Haq MP, Dr. Yakub Ali, Dr. Badiuzzaman, Abed ali, Tulsiram Agarwala, Jamuna Prasad Kedia, Harihor Prasad, Rameswar Pal and three trucks of people. The eye witness Kamala Prasad said-

With my own eyes, I saw the Pakistani militaries taking people in two trucks among which I recognized Tulsiram Agarwala and Harihor Prasad. They took the trucks to Balar Khal (canal of sands). Beforehand, they took me there with another truck. My hands and legs were bound. When they opened our hands and legs and told to stand on queues, I ran away and could save my life.

On $12^{\text {th }}$ April ' 71 , three hundred (300) Maroaris (non-Muslims) were taken from Saidpur to the cantonment of Rangpur. All of them were killed inside the cantonment. The place is yet to be identified.

$13^{\text {th }}$ April, 1971, Pak militaries killed eleven (11) Bengali soldiers on Rangpur-Kurigram road. The spot is known as Nabdiganj execution field.

From the supplementary page on liberation of a local weekly of Rangpur called "Atal", it is known that-

In the unions of Pairaband at Jairam Anwar mouza innumerable people were killed in two execution fields. The fields are almost lost into oblivion (The Dainik 'Atal', $16^{\text {th }}$ December, 2000.). 
Mafiz Uddin (75), a witness from Jairam, informs that at the mid night of $22^{\text {nd }}$ April ' 71 , Pakistani armies carried people to Jairam execution field using five (05) trucks. Mafiz Uddin lost two of his sons. He said, approximate number of victims was at least five hundred (500).

Again, through inspection, observation, interviewing and focus group discussion as well as from the book related to Rangpur, published by the ministry of Information, the following data have been collected-

$1^{\text {st }}$ May, 1971, nineteen (19) Bengali soldiers were taken five kilo metres east from Rangpur city at Shahebganj under Tapodhon union. This execution field is known as Bircharan execution field. Here each of the dead bodies was identified as wrapped with ropes. More E.P.R soldiers were killed at night on $14^{\text {th }}$ May ' 71 . The next day, villagers observed sixty (60) dead bodies of E.P.R at the side of the river Ghaghot. These dead bodies could not be buried because there was Fatwa (directives) by the Pak-militaries that -"Bengalis are not Muslims; they don't need to be buried."

Asim Uddin, an inhabitant of Darshana area and a witness claimed-

The lower part of Jafarganj Bridge is certainly an execution field. Some legendary people like advocate Pakhi Mitra, Roni Rahman, Shiben Mukharjee, Aswini Ghosh were killed under the bridge.

During liberation war, "Modern Cinema Hall" and "Rangpur Betar Kendra" were made Torture Cells by the Pak militaries. The Modern Cinema Hall is the present "Town Hall" beside the public library of Rangpur. Beside from the town hall, eighty seven (87) dead bodies of women were obtained from a well.

Ahsan Mia, a rickshaw puller, an inhabitant of Gangachara, could escape from being slaughtered at the execution field of Rangpur Town Hall. In his opinion, three hundred and fifty (350) people had been slaughtered on a single day, near about two months before the independence. He said that the homicide began before his eyes. He saw and recognized Zinki Malika, Ali Hossen, and Farukh Mia were being slaughtered. The field is situated at the back side of Rangpur Town Hall.

To the east from Rangpur city through Central road, there is Dahiganj Shasman (Place of burning dead bodies of Hindus). On the 
black night of $25^{\text {th }}$ March, 71, Pak militaries began "Operation Search Light" simultaneously on Dhaka and, also, on Rangpur. That night twelve professionals were taken to Dahiganj Shasman and were killed including advocate A.Y. Mahmud alias Jorres Mian. Bankim Chandra, a Shadhu (who lives in the shasman) living at Dahiganj Shasman for last fifty years, told-

The search light was on. The entire area was flashed. Twelve people were standing on a line at the western part of the Shasman. Then they fired and the whole area was terrified. A man known as Montu Doctor, could escape.

Md. Aminul Islam, a reporter of Dainik Bangla, 1972, marked the entire Rangpur district as a mass execution field. He wrote-

Here and there at every town of the district, there are so many execution fields that no one can count up. There are instances that a thousand of people had been killed in a single execution field.

Indeed, the invaders damaged twenty nearly thousand $(20,000)$ houses and killed approximately fifty thousand $(50,000)$ people at Rangpur thana by launching the genocide. Till the present time, the research finds fifty one (51) mass execution fields in which thousands of people had been buried down. The researcher predicts that through further researches, more execution fields may be identified with an increased number.

\section{Present Position of the Exaction Fields}

Physically visiting the places, it has been found that except Nabdiganj, Nishbetganj, Lahirir Hat and Bircharan, almost all of the execution fields of Rangpur are on the way to extinction. Most people do not know that there are execution fields in the locations. Most of the fields are getting occupied with farming and business entrepreneurs.

Especially, one of the biggest mass execution fields is located in the present Rangpur cantonment and around the cantonment and there are other execution sites scattered. Still, the cantonment does not expose any interest to mark the locations of the fields or pay homage to those fields. 
Some execution fields are simply neglected. And some, like that of Ghoda Pir Mazar, has become the sanctuary of the druggists.

Many of the young generations do not know what the word "Bodhya Vumi" means. New generation people have too rarely any idea of the locations of the execution fields. Consequently, most fields are getting lost into oblivion.

\section{Findings of the Research}

1. The city Rangpur had political turmoil from before the historic speech by Bangabandhu on $7^{\text {th }}$ march, 1971.

2. Indeed, genocide started at Rangpur city from $3^{\text {rd }}$ March, 1971 killing a group of people at Ghodapir Mazar area.

3. Shanku Shamajhdar, the first of the killed ones on $3^{\text {rd }}$ March, 1971 may be considered to be the first martyr of liberation movement.

4. The Santal Revolt at Rangpur against the Pakistani rulers is a distinguished phenomenon in the war of liberation.

5. People of Rangpur attacked the armies and killed all of the team including lieutenant Abbas on $17^{\text {th }}$ March. It demonstrates that the war actually began at Rangpur before the formal declaration of liberation on $25^{\text {th }}$ March.

6. The study finds fifty one (51) mass execution fields created in the genocide at Rangpur Thana during the liberation war of Bangladesh in 1971.

7. The execution fields where thousands of people were slaughtered are nine (09).

8. The execution fields where five hundred (500) to one thousand (1000) people were killed are four (04).

9. The execution fields where one hundred to five hundred people were killed are three (03).

10. The execution fields where less than one hundred people were killed are thirty five (35) in number.

11. Mass execution fields where approximately, one thousand (1000) to five thousand (5000) people had been killed are: 
Rangpur Cantonment Mass Graves, Rangpur Radio Centre, Nishbetganj, Lahirir Hat, Baldipukur, Balar Khal, Modern Cinema or Present Town Hall, Bank of the River Ghaghot, Military Shed of Rangpur Cantonment etc.

12. The execution fields where approximately five hundred (500) to one thousand (1000) people were killed are: Damodarpur, the Five (5) Kilo Metre Long Road West to the Monument "Rakta Gaurabi”, Back Side of Rangpur Parjatan Kendro, Main Road of The Village Nishbetganj etc.

13. The execution fields where one hundred (100) to five hundred (500) people were killed are: Khalifa Tari, Residence of Major Bashir, Upa Shahar etc.

14. The execution fields where less than one hundred (-100) people were killed are:

Ghoda Pir Majar, Haragas Road, back side of Rangpur Autopsy, Rangpur-Dhaka Road, Chandanpat, C.O Bazar, West Side of Rangpur Cantonment, North-West Side of Rangpur Cantonment, Southern Part of Rangpur Cantonment, The South-East Side of Rangpur Cantonment, West Side of Rangpur Cantonment, Manjai, Darshana, Darshana Pahari, Kholahati, Deovog, Damodorpur, North-West Corner of Deovog, Damdama Bridge, Dhap Mor, Darshana Pahadi, Garage of The Cantonment, Narir Hat, Radha Ballav, Tajhat, Mahiganj, Modern , Rangpur-Saidpur Road, Harirampur, Nabdiganj, Pairaband, Jairam, Bircharan, Jafarganj Bridge, Dahiganj Shasman etc.

15. In the genocide nearly 20,000 houses were abolished and approximately 50,000 people were killed.

16. The execution fields of Rangpur are getting through extinction in two ways: first, with the passage of time, number of witnessing people is decreasing and it is day by day becoming more difficult to get authentic men to identify the locations of the fields and secondly, the fields are changing in their physical structures e.g. being used for cultivation, habitation or occupied by the developers. 


\section{Conclusion}

The Pak-invading armies conducted monstrous genocide at the city of Rangpur during the liberation war of Bangladesh in 1971. The theory of their leader Iahia Khan "Man not, land" had been applied to the point by the invading militaries. The massacre that they made was so arbitrary that the fifty one (51) mass execution fields, which the present research has found, may be on the increase in number through further researches in future. It seems that the undiscovered execution fields may surpass the number of the discovered execution sites in future. The most sorrowful finding of the research, in perspective of the present reality, is that most execution fields are on the way to extinction. That is why; it is high time, more intensive research could be initiated on behalf of the government, policy makers, researchers and the academicians to save the execution fields from being extinct. 


\section{References}

Ahsan, Qazi. (1994). Shaheed Mukhtar Elahi abong Rangpur $e$ Muktijuddha [The Martyr Mukhtar Elahi and Liberation War at Rangpur], ed. Qazi Ahsan, Rangpur: Shaheed Mukhtar Elahi Trust.

Biswash, Sukumar. "'71-er Gana Kabar- Boddhya Vumi: Rangpur" [Mass Graves and the Execution Fields of '71: Rangpur], in The Martyr Mukhtar Elahi and Liberation War at Rangpur

Chawdhury, Wahiduzzaman. (1974). Bangladesher Swadhinota Juddher Itihas: Dalilpatra, \{History of Liberation War of Bangladesh: Facts and Documents\}, ed. M.R. Akhtar Mukul.

Mandal, Akhtaruzzaman. (1974) Uttar Ranangane Bijoy \{1971: Victory on the Northern Front\}, Dhaka: Hakkani Publishers. 